\title{
O XAMANISMO NA LITERATURA INDÍGENA BRASILEIRA: DA AUTOEXPRESSÃO E AUTOAFIRMAÇÃO IDENTITÁRIAS AO CRITICISMO SOCIAL E À RESISTÊNCIA POLÍTICA: NOTAS DESDE A QUEDA DO CÉU: PALAVRAS DE UM XAMÃ YANOMAMI, DE DAVI KOPENAWA E BRUCE ALBERT
}

\section{THE SHAMANISM IN THE BRAZILIAN INDIGENOUS LITERATURE: FROM IDENTITY SELF-EXPRESSION AND SELF-AFFIRMATION TO SOCIAL CRITICISM AND POLITICAL RESISTANCE: NOTES FROM DAVI KOPENAWA'S AND BRUCE ALBERT'S THE FALLING SKY: WORDS OF A YANOMAMI SHAMAN}

\author{
Leno Francisco DANNER ${ }^{1}$ \\ Julie DORRICO ${ }^{2}$
}

\begin{abstract}
Resumo: Argumentamos que a literatura indígena brasileira recente tem se servido do xamanismo como correlação de autoafirmação e de autoexpressão identitárias, em que a própria base antropológico-ontológica e sociocultural comunitária é ativada e utilizada como substrato da compreensão e da manifestação do indígena por si mesmo, $e$, a partir daqui, como ferramenta epistemológico-normativa de resistência cultural e de luta política relativamente à modernização imposta tecnocraticamente, assim como à violência e à negação sofridas enquanto minoria sociocultural. O xamanismo, reestilizado como voz-práxis literária, permite o reconectar-se e o enfatizar-se da tradição, do eu-nós coletivo (que se torna o eu-nós lírico) do discurso-práxis indígena, em que esse mesmo eu-nós fala por si mesmo e desde si mesmo, sem mediações políticas e cientificistas. Nesse sentido, o xamanismo na e como literatura indígena permite a voz-práxis do eunós comunitário, calcado na tradição ancestral, enfatizando-a como fundamento de si e utilizando-a como substrato da crítica e da luta públicas.
\end{abstract}

Palavras-Chave: Literatura. Xamanismo. Autoafirmação. Resistência-Luta.

Abstract: We argue that recent Brazilian Indigenous literature has been using the shamanism as correlation of identity self-affirmation and self-expression, in which the own communitarian anthropological-ontological and social-cultural basis is activated and utilized as substratum of the comprehension and manifestation of the indigenous by himself, and, from here, as epistemologicalnormative tool for cultural resistance and political struggle in relation to the modernization imposed technocratically, as well as to the violence and negation suffered as social-cultural minorities. The shamanism, re-stylized as literary voice-praxis, allows the reconnecting and the emphasizing with tradition, of the "I-We" (who becomes the literary "I-We") of the Indigenous discourse-praxis, in which this "I-We" speaks for and from himself, without political and scientifical mediations. Therefore, the shamanism in and as Indigenous literature enables the voice-praxis of the "I-We" communitarian, based on ancestral tradition, emphasizing it as fundament of itself and using it as substratum of public criticism and struggle.

Key-Words: Literature. Shamanism. Self-Affirmation. Resistance-Struggle.

\footnotetext{
${ }^{1}$ Doutor em Filosofia (PUC_RS). Professor de Filosofia e de Sociologia no Departamento de Filosofia da Fundação Universidade Federal de Rondônia UNIR).

${ }^{2}$ Doutoranda em Teoria Literária pelo Programa de Pós-Graduação em Letras da Pontifícia Universidade Católica do Rio Grande do Sul (PUCRS). Mestre em Estudos Literários e Licenciada em Letras Português e suas respectivas Literaturas pela Universidade Federal de Rondônia (UNIR).
} 
Os brancos se dizem muito inteligentes. Não o somos menos. Nossos pensamentos se expandem em todas as direções e nossas palavras são antigas e muitas. Elas vêm de nossos antepassados. Porém, não precisamos, como os brancos, de peles de imagens para impedi-las de fugir de nossa mente. Não temos de desenhá-las, como eles fazem com as suas. Nem por isso elas irão desaparecer, pois ficam gravadas dentro de nós. Por isso, nossa memória é longa e forte. O mesmo ocorre com as palavras dos espíritos xapiri, que também são muito antigas. Mas voltam a ser novas sempre que eles vêm de novo dançar para um jovem xamã, e assim tem sido há muito tempo, sem fim. Nossos xamãs mais antigos nos dizem: "Agora é sua vez de responder ao chamado dos espíritos. Se pararem de fazê-lo, ficarão ignorantes. Perderão seu pensamento e, por mais que tentem chamar a imagem de Teosi para arrancar seus filhos dos seres maléficos, não conseguirão" (KOPENAWA e ALBERT, 2015, p. 75).

\section{Considerações iniciais}

Estamos assistindo com uma impressionante intensidade e pungência à atuação públicopolítica do movimento indígena brasileiro e de lideranças e intelectuais a ele ligados, em uma atitude política e politizante de permanente autoafirmação, crítica social e denúncia política da situação de marginalização e de violência que sofrem, mas também como forma de reivindicação da própria identidade e, em ambos os casos, da sua singularidade como ponto de partida para pensar-se e orientar-se a questão indígena mesma enquanto política pública e preocupação institucional brasileiras. Isso significa duas coisas: primeiro, os povos indígenas querem que sua voz-práxis seja ouvida no que diz respeito à formulação de políticas públicas e ao arranjo institucional referentemente à questão indígena; segundo, eles passaram a publicizar de modo direto e permanente sua própria condição, seus problemas, sua luta e, subsumindo e embasando tudo isso, sua perspectiva antropológico-ontológica, sociocultural e epistemológico-política. Sua voz-práxis não apenas é profundamente enraizada em termos público-políticos, senão que também representa uma forma de autoafirmação e de autoexpressão em que a perspectiva de mundo indígena passa para primeiro plano seja no que tange à valorização do indígena por si mesmo, seja no que diz respeito à sua atuação sociopolítica, em termos de crítica e de luta-resistência.

É nesse sentido que lideranças e intelectuais indígenas lançam mão de modo muito intenso das mídias (configurando, inclusive, o que se está chamando de etnomídia) e em especial, para nosso caso aqui, da arte e da literatura como forma de autoexpressão e de autoafirmação de si mesmos e, como consequência, de resistência cultural e de luta política (DORRICO, 2017; ALMEIDA e QUEIROZ, 2004; D'ANGELIS, 2007). A literatura indígena, aliás, teve das últimas duas décadas para cá um incremento verdadeiramente 
impressionante, ao ponto de nós a considerarmos uma das bases epistemológicas, políticas e normativas para a disseminação da cultura e da resistência indígenas, para sua publicização e expansão seja no âmbito das ciências humanas e sociais (saindo, por conseguinte, de uma abordagem predominantemente antropológica e adentrando em esferas como a literatura, a filosofia, a teoria política etc.), seja na sociedade civil de um modo mais geral, mas também, em primeiro lugar, para sua autoexpressão e autoafirmação identitárias que servem de base para as consequentes resistência cultural e luta política. Ora, é aqui que a reestilização do xamanismo ocupa um lugar central na e dinamiza, singulariza e politiza a literatura indígena como voz-práxis dos sujeitos indígenas por eles mesmos, a partir da correlação de autoafirmação e autoexpressão identitárias e resistência e luta político-culturais.

Se trata, por assim dizer, de uma reestilização do xamanismo na medida em que ele passa a ser utilizado em termos epistemológico-políticos como base e mote da expressão público-política indígena e de sua crítica e de sua luta em relação à modernidademodernização. Aqui, o indígena já não necessita mais assumir o próprio paradigma normativo da modernidade, em seu modelo cientificista (como racionalização epistêmica e como procedimentalismo imparcial, neutro, formal e impessoal em termos normativos), para expressar-se e para significar tanto sua voz-práxis quanto sua consequente resistência-luta político-cultural. No mesmo sentido, ele já não necessita ser representado pelo cientista social (incluindo-se, aqui, o antropólogo, o filósofo e o próprio político) extemporâneo, simpático a ele evidentemente, mas portador do método para a expressão e a significação objetivas da condição, do drama e da reivindicação desse mesmo indígena localizado em um tempo, em um modo e em uma condição pré-científicas. O xamanismo enquanto voz-práxis literária dos indígenas por si mesmos e a partir de si mesmos prescinde do cientificismo moderno, sendo plenamente capaz de sustentar a autoafirmação identitária e a singularidade antropológicoontológica e sociocultural dos indígenas por si mesmos, bem como, a partir daqui, de fundar uma práxis de resistência e de luta contra a violência e a negação sofridas, contra a imposição verticalizada, unidimensional e tecnocrática dos projetos de modernização como solução aos seus supostos arcaísmo e atraso epistêmicos, políticos, socioculturais e econômicos.

No texto, nós queremos explicitar e argumentar sobre como o xamanismo na literatura indígena, por meio dela e a partir dela, se baseia nessa correlação de autoafirmação e autoexpressão identitárias e sua consequente resistência-luta político-cultural em relação à modernização. Tendo por base a análise da obra A Queda do Céu: Palavras de Um Xamã Yanomami, produto da parceria entre Davi Kopenawa e Bruce Albert, nós procuraremos 
refletir seja sobre a correlação acima expressa, seja, a partir dela, sobre a novidade e a importância da conexão entre movimento indígena - nas suas variadas manifestações, desde produções autorais individualizadas até a participação artístico-cultural-literária coletiva - e literatura, movimento indígena como literatura, que permite concomitantemente (a) a conquista de um público e de um espaço socioculturais mais amplos que aquele do especificamente âmbito acadêmico e (b) a própria desconstrução do cientificismo (o que chamamos, acima, de paradigma normativo da modernidade) como ferramenta metodológica e critério normativo para a expressão da voz-práxis dos indígenas por si mesmos, permitindolhes, em grande medida, prescindirem da mediação do cientista social e dos paradigmas científico-normativos para sua publicização e para seu enquadramento da modernização. Nesse caso, a literatura como voz-práxis dos indígenas por si mesmos possibilita-lhes o falar, o significa e o agir em primeira pessoa do singular e terceira pessoa do plural, a correlação do eu-nós lírico em que eles mesmos interagem publicamente e chamam a atenção sociopolítica para sua condição. Repetimos mais uma vez: isso não seria possível sem a centralidade, na literatura indígena, do xamanismo como voz-práxis indígena em primeira pessoa do singular, mas também em nome do nós comunitário, da terceira pessoa do plural.

Apenas a título de esclarecimento, queremos enfatizar que estamos entendendo a obra $A$ Queda do Céu: Palavras de Um Xamã Yanomami como um texto literário (o que não exclui outras conceituações dela, evidentemente). Em verdade, esse texto-práxis possui um compósito de classificações. Ele é chamado de depoimento-profecia, de relato autobiográfico, de biografia singular, de reflexão xamânica, de documento diplomático exemplar, sessão xamânica, tratado político, relato de vida e compêndio de filosofia yanomami; essas são algumas categorizações existentes que podemos assinalar, conforme Bruce Albert e Viveiros de Castro (VIVEIROS DE CASTRO, 2015, p. 19-27; ALBERT, 2015, p. 39, p. 537). Diante dessa pluralidade de formas atribuídas à obra, que não a reduz a uma disciplina e a um campo epistêmico específicos, senão que aponta para epistemologias-outras, pensamos ser possível analisá-la sob o prisma dos estudos literários contemporâneos, que compreende em si a manifestação plural de vozes antes subalternizadas e silenciadas como consequência de uma tradição estritamente escolástico-literária própria ao cânone cientificista e institucional de nossa academia. Nesse sentido, entendemos a obra A Queda do Céu como literatura indígena dado o campo plurissignificativo a que ela se abre. Isso quer dizer que, a partir de estudos sobre a autobiografia indígena, postulados por Oscar Sáez, Suzanne Lima Costa e Rafael Xucuru, pensamos ser possível estudá-la na fronteira dos estudos literários que, por sua vez, 
tangenciam os estudos de antropologia, das ciências políticas e sociais, mas que não a reduzem, como dito acima, a essas áreas em sentido estrito (SÁEZ, 2006; COSTA, 2014; COSTA e XUCURU-KARIRI, 2014).

A literatura indígena, como sua especificidade mais estrita, traz, em seu corpus, um conjunto de saberes que não se circunda à escrita alfabética, mas que valoriza o conhecimento da e a imbricação com a natureza que se manifestam em todas as suas práticas sociais. Ela projeta no livro, que é um instrumento e meio de seu sistema literário, e não sua finalidade última, outras formas de saberes tradicionais que estão para além da compreensão da literatura moderna: a dança, o canto, a poesia travestida de diálogo com os ancestrais, os rituais, as cerimônias de passagem, as narrativas xamânicas passadas de geração em geração, de modo que tudo isso, no âmbito indígena, é expressão artístico-literária. A literatura indígena possui, ainda, em seu sentido estético-cultural, uma profunda vinculação política, ligando-se diretamente ao movimento indígena. Essa sua dupla característica - de ser mais ampla do que o texto escrito e de estar profundamente vinculada em termos políticos ao movimento indígena - significa que a literatura indígena possui seu próprio conceito de literariedade, a correlação triádica de oralidade, saberes ancestrais e movimento político, que reafirma seu próprio deslocamento no âmbito cultural - da oralidade para a escrita - com vistas a uma resistência e a uma luta contra a violência simbólica, política e material que os povos indígenas sofrem (BONVINI, 2006). Assim, a literatura indígena, em nossa contemporaneidade, compreende manifestações plurais em termos antropológico-ontológicos, ritualísticos, culturais, simbólicos e estéticos, que podem ser analisados na academia por disciplinas que vão desde a antropologia, passando pela história, pela sociologia, pela filosofia e chegando-se à literatura (que é o nosso caso aqui). Isso quer dizer que o próprio conceito de literatura indígena, que está em construção dada a relativa novidade dessa mesma produção literária indígena brasileira, é complexo e plural, compreendendo fenômenos que destoam dos paradigmas literários estritos de nossa academia, calcada e dinamizada por gêneros literários definidos e expressos sobretudo sob a forma de texto escrito. A literatura indígena, portanto, apresenta elementos que a caracterizam enquanto manifestação ameríndia, tais como: a heterogeneidade autoral, a expressão xamânica, a imbricação entre eu-nós lírico, a correlação de sujeito mítico e sujeito histórico etc. 


\section{Sobre a voz-práxis xamânica indígena como correlação de autoafirmação antropológico- ontológica e crítica à modernidade: notas desde a literatura indígena}

Como estamos argumentando, o xamanismo é utilizado na e como literatura indígena de modo a viabilizar duas perspectivas normativo-políticas fundamentais e correlacionadas, a saber: a autoafirmação e a autoexpressão do indígena por si mesmo e sua resistência e luta em relação à modernização, pontos esses que, de todo modo, não podem ser separados em termos de movimento indígena, posto que sua autoafirmação parte exatamente do fato da modernização, do fato do colonialismo, como o lócus, o fundamento e o próprio sentido de sua marginalização, de sua violência, de sua destruição, de sua situação como minoria, como diferença - se são minorias, isso o foi exatamente pelo e por causa do processo de colonização em nome de uma modernidade alheia, unidimensional e totalizante. Nesse diapasão, o xamanismo permite singularizar, dinamizar e, em consequência, dar carnalidade e politicidade à voz-práxis indígena como sua mais característica e qualidade mais específica. No mesmo sentido, e isso é muito importante, a voz-práxis xamânica devolve ao indígena seja o direito de dizer a sua palavra e de performar a sua práxis, seja a possibilidade de ser si mesmo nesse dizer sua palavra e performar sua práxis. Aqui, ele não precisa de mediação e nem de representação por alguém alheio, que adéqua seu discurso e estiliza sua práxis de acordo com e com base em uma perspectiva cientificista extemporânea.

É por isso que o xamanismo na e como literatura, enquanto a explicitação mais direta e pungente do ser indígena, de sua condição, de sua autoexpressão, situa a voz-práxis desse mesmo indígena no seu próprio lugar antropológico-ontológico e sociocultural, conformandoa ao seu estatuto epistemológico-político. Aqui, portanto, temos uma autoexpressão genuína que, uma vez percebida por ele como condição fundante e definidora de si mesmo, como fundamento normativo válido da crítica e da ação, lhe permite utilizar-se dela publicamente como forma de mediação do diálogo-práxis intercultural, em que a modernidademodernização, vista por ele como o problema - essa mesma modernidade-modernização que, ao contrário, vê o homem tradicional ou pré-moderno como seu problema epistemológicopolítico - passa a ser enquadrada, avaliada e criticada (talvez até transformada) desde a vozpráxis indígena em termos de xamanismo. Nesse sentido, o xamanismo na e como literatura performa e realiza sua luta-práxis desde seu próprio lugar e a partir de seus fundamentos antropológico-ontológicos, socioculturais e epistemológico-políticos: aqui, se a modernidademodernização tem de ser enquadrada, ela o será pelo próprio xamanismo e em seus termos; se o diálogo-intercultural tem de ser travado, ele o será a partir da própria explicitação da visão 
xamânica e de sua chamada à responsabilidade à voz-práxis branca; e, se a marginalização, a violência e a negação sofridas têm de ser denunciadas e combatidas, elas o serão exatamente em termos de expressão xamânica.

É nesse contexto que afirmamos que o xamanismo na e como literatura possibilita, ao movimento indígena, a seus intelectuais e lideranças, a correlação de autoexpressão e autovalorização internas com resistência e luta público-políticas. Não por acaso, Davi Kopenawa menciona exatamente esse núcleo, essa correlação como mote da construção, do sentido e da intenção d'A Queda do Céu: Palavras de Um Xamã Yanomami. Dirigindo-se, logo no início, a Bruce Albert, co-autor da obra, ele diz: "Então, entreguei a você minhas palavras e lhe pedi para levá-las longe, para serem conhecidas pelos brancos, que não sabem nada sobre nós. [...] Assim, eu lhe dei meu histórico, para você responder aos que se perguntam o que pensam os habitantes da floresta" (KOPENAWA e ALBERT, 20015, p. 63). Note-se, aqui, os dois pontos fundantes da obra em comento: o que pensam os yanomamis sobre si mesmos em termos antropológico-ontológicos, socioculturais e epistemológico-políticos e o que eles pensam e como veem o processo de modernização sociocultural e político-econômica porque, ao longo do texto, é essa dupla e correlata perspectiva que é assumida e dinamizada a partir do relato autobiográfico do xamã e sob a forma de interpretação xamânica de si e da própria modernização; e o exercício de comunicar aos brancos o que efetivamente pensam os yanomamis sobre si e sobre essa mesma modernização.

Ora, em primeiro lugar e de modo fundamental, a própria construção autobiográfica d' $A$ Queda do Céu imbrica inextricavelmente destino coletivo e história pessoal, ancestralidade e vida atual ou presente, autoconstituição antropológico-ontológica e interpretação epistemológico-política, pólos aos quais o xamanismo expresso e assumido por Davi Kopenawa não separa em momento algum, pólos aos quais, em verdade, ele se remete do começo ao fim do diálogo como fundamento de sua auto-compreensão identitária e de sua avaliação e de seu enquadramento do processo de modernização. De todo modo, é essa história do próprio povo yanomami e de seu contato direto, via xamanismo, com Omama e seus Xapiri, respectivamente seu demiurgo e seus espíritos protetores (da floresta, dos povos indígenas e dos próprios brancos), que Davi Kopenawa quer explicar e dar a conhecer aos brancos, seja porque considera que esse conhecimento pode ajudar a dirimir pré-conceitos relativamente ao suposto arcaísmo ou à falta de sabedoria dos indígenas, muito comuns entre os brancos, seja porque ele acredita que a posição antropológico-ontológica própria a seu povo tem muito a dizer à modernização mesma, especialmente quando esta assimila, coloniza 
e, paulatinamente, destrói os povos tradicionais em nome do progresso e do desenvolvimento econômico. É uma autoexpressão de si ao outro, como crítica, resistência e luta, como um chamamento ao diálogo e à moderação. Senão vejamos a voz-práxis de Davi Kopenawa:

Como eu, você ficou mais experiente com a idade. Você desenhou e fixou essas palavras em peles de papel, como pedi. Elas partiram, afastaram-se de mim. Agora desejo que elas se dividam e se espalhem bem longe, para serem realmente ouvidas. $\mathrm{Eu}$ lhe ensinei essas coisas para que você as transmita aos seus; aos seus mais anciãos, aos seus pais e sogros, aos seus irmãos e cunhados, às mulheres que você chama de esposas, aos rapazes que irão chamá-lo de sogro. Se lhe perguntarem: "Como você aprendeu essas coisas?", você responderá: "Morei muito tempo nas casas dos Yanomami, comendo sua comida. Foi assim que, aos poucos, sua língua pegou em mim. Então, eles me confiaram suas palavras, porque lhes dói o fato de os brancos serem tão ignorantes a seu respeito".

Os brancos não pensam muito adiante no futuro. Sempre estão preocupados demais com as coisas do momento. É por isso que eu gostaria que eles ouvissem minhas palavras através dos desenhos que você fez delas; para que penetrem em suas mentes. Gostaria que, após tê-las compreendido, dissessem a si mesmos: "Os Yanomami são gente diferente de nós e, no entanto, suas palavras são retas e claras. Agora entendemos o que eles pensam. São palavras verdadeiras! A floresta deles é bela e silenciosa. Eles ali foram criados e vivem sem preocupação desde o primeiro tempo. O pensamento deles segue caminhos outros que o da mercadoria. Eles querem viver como lhes apraz. Seu costume é diferente. Não têm peles de imagens, mas conhecem os espíritos xapiri e seus cantos. Querem defender sua terra porque desejam continuar vivendo nela como antigamente. Assim seja! Se eles não a protegerem, seus filhos não terão lugar para viver felizes. Vão pensar que a seus pais de fato faltava inteligência, já que só terão deixado para eles uma terra nua e queimada, impregnada de fumaças de epidemia e cortada por rios de águas sujas!”. Gostaria que os brancos parassem de pensar que a nossa floresta é morta e que ela foi posta lá à toa. Quero fazê-los escutar a voz dos xapiri, que ali brincam sem parar, dançando sobre seus espelhos resplandecentes. Quem sabe assim eles queiram defendê-la conosco? Quero também que os filhos e filhas deles entendam nossas palavras e fiquem amigos dos nossos, para que não cresçam na ignorância. Porque, se a floresta for completamente devastada, nunca mais vai nascer outra. Descendo desses habitantes da terra das nascentes dos rios, filhos e genros de Omama. São as palavras dele, e as dos xapiri, surgidas no tempo do sonho, que desejo oferecer aqui aos brancos. Nossos antepassados as possuíam desde o primeiro tempo. Depois, quando chegou a minha vez de me tornar xamã, a imagem de Omama as colocou em meu peito. Desde então, meu pensamento vai de uma para outra, em todas as direções; elas aumentam em mim sem fim. Assim é. Meu único professor foi Omama. São as palavras dele, vindas dos meus maiores, que me tornaram mais inteligente. Minhas palavras não têm outra origem. As dos brancos são bem diferentes. Eles são engenhosos, é verdade, mas carecem muito de sabedoria (KOPENAWA e ALBERT, 2015, p. 64-65).

Essa passagem, conforme pensamos, é riquíssima de pressupostos e de consequências teórico-políticos, aos quais gostaríamos de desenvolver melhor no que se segue. Primeiramente, veja-se a referência sempre permanente a Omama e aos seus xapiri, assim como aos próprios antepassados yanomami do primeiro tempo, que são filhos e genros de Omama; no mesmo sentido, perceba-se a referência sempre permanente às palavras de Omama, que os yanomami sempre guardaram e mantiveram rememoradas e publicizadas, via 
xamanismo, bem como o próprio fato de que Davi Kopenawa, como xamã, assume a sua vocação, uma vez tendo chegado seu tempo, de transmiti-la aos seus e aos brancos. Aqui está o núcleo simbólico, político e normativo do xamanismo de Davi Kopenawa tal qual expresso e desenvolvido n’A Queda do Céu, núcleo esse que também define o sentido e o direcionamento dados a ela, a saber, da autoafirmação e da autoexpressão identitárias, em termos antropológico-ontológicos, à resistência, à luta, ao diálogo-práxis intercultural, todo esse processo perpassado pela vinculação e pela destinação originária do povo yanomami de que Davi Kopenawa faz parte e cuja tarefa de rememoração, de fomento, de defesa e de publicização agora cabe a ele como xamã, uma vez tendo experienciado essa ligação umbilical e ancestral com Omama, uma vez tendo visto e experienciado os xapiri guardiães e protetores da floresta com todos os seres que vivem ali, dela dependentes (incluindo indígenas e brancos).

Em segundo lugar, é importante ressaltar a intenção do diálogo-práxis intercultural, assim como a perspectiva de que talvez os filhos dos indígenas e os filhos dos brancos pudessem construir relações cordiais e amistosas que lhes permitissem seja conhecerem-se mutuamente, se isso for possível em sentido estrito, seja respeitarem-se e cooperarem mutuamente com vistas à proteção da floresta - o que significa, de modo direto e consequente, a proteção de ambos, indígenas e brancos à medida que se protege a floresta. Esse diálogo-práxis (e a própria amizade entre os filhos de uns e de outros) é importante porque, em verdade, os brancos, como arautos e defensores da modernização, efetivamente ocasionam a gradativa destruição tanto dos indígenas quanto da floresta, e isso de modo concomitante, já que os indígenas dependem da integridade de suas florestas como questãochave para sua sobrevivência, assim como a destruição daqueles equivale à própria destruição desta - os indígenas não seriam destruídos não fossem intenções comerciais, mercantilistas e instrumentais dos brancos relativamente à floresta e à terra, isso é óbvio ${ }^{3}$. Pois bem, dar-se a conhecer aos brancos como se é, como se constitui sua sociedade-cultura e como pensa enquanto povo, explicitar aos brancos como os yanomamis estão umbilicalmente ligados ao seu horizonte antropológico-ontológico, aos seus deuses e aos espíritos, bem como dependentes deles, da floresta e da terra, isso é o que almeja Davi Kopenawa sob a forma d'A Queda do Céu: talvez em conhecendo-os - e a grande metáfora epistemológico-normativa da modernidade é o conhecer científico como condição do sentido e da práxis - se possa

\footnotetext{
3 “[...] são eles que nos matam com suas doenças e com suas espingardas" (KOPENAWA e ALBERT, 2015, p. 73).
} 
respeitá-los, considerá-los iguais ou, pelo menos, merecedores de respeito, concedendo-lhes o direito da palavra relativamente a si mesmos e à própria modernização. Porque, como estamos insistindo, o mote central de voz-práxis xamânica de Davi Kopenawa e sua expressão literária n'A Queda do Céu é exatamente uma crítica à modernização, aos brancos (que ele correlaciona com a modernização, como seus arautos, representantes e realizadores), por meio de uma autoafirmação antropológico-ontológica e de sua autoexpressão via xamanismo como lugar do sentido, da crítica e da práxis.

Dito isso, é importante, em terceiro lugar, atentar-se para uma passagem fundamental da citação acima, a saber, a tentativa, por Davi Kopenawa, de explicar e de dar a conhecer aos brancos o fato de que a floresta não é uma coisa mecânica, instrumental ou puramente física, ou até morta, como se ela fosse um objeto puro e simples, destituída por completo de normatividade, de sentimento, senão que totalmente perpassada por vida, prenhe dela, e isso não apenas em um sentido biológico, mas também e principalmente em um sentido ontológico, mágico. Com efeito, ela foi feita e ordenada por Omama e nela vivem os xapiri, os espíritos animais que foram criados por Omama para protegerem-na e para protegerem os indígenas e os brancos. Ela possui ordem e normatividade, e isso não apenas porque foi feita pelo próprio deus Omama, sendo também perpassada e dinamizada pelos espíritos xapiri, senão que por fazer parte da própria teia da vida na qual os seres humanos têm o seu lugar como uma forma de vida entre outras. Por isso mesmo, uma floresta viva não pode ser destruída, objetificada, instrumentalizada ou tornada mercadoria, porque essa condição de coisa certamente não contempla o sentido e a constituição da própria floresta, muito menos sua abrangência, e em verdade contribui seja para a incompreensão humana relativamente a ela, seja para uma ação destrutiva porque instrumental, coisificadora. Nesse caso, a diferenciação entre res cogitans e res extensa cartesiana, ao separar homem-humanidade e natureza, normatividade (homem) e coisa (natureza), separação essa que é um dos fundamentos antropológico-ontológicos e epistemológico-políticos da modernidademodernização (e aplicada também aos próprios povos indígenas), não permite nem a promoção e a proteção da floresta e nem a chance de existência aos indígenas, seu direito a ser e a viver em profunda conexão com uma floresta vida e geradora, garantidora de vida. É nesse sentido complexo de criação mítico-religiosa, de interpretação xamânica e de necessidade existencial-material que os indígenas assumem a proteção da floresta e da terra como sua vocação mais essencial - é nesse sentido, por conseguinte, que Davi Kopenawa orienta sua voz-práxis de denúncia, resistência e luta: 
Nossa língua é aquela com a qual ele (Omama) nos ensinou a nomear as coisas. Foi ele que nos deu a conhecer as bananas, a mandioca e todo o alimento de nossas roças, bem como todos os frutos das árvores da floresta. Por isso, queremos proteger a terra em que vivemos. Omama a criou e deu para que vivêssemos nela. Mas os brancos se empenham em devastá-la e, se não a defendermos, morreremos com ela (KOPENAWA e ALBERT, 2015, p. 74).

Ora, é aqui, na explicitação e na interpretação dessa ligação entre espiritualidade e materialidade, que o xamanismo assume, em termos de esfera público-política de um modo geral e de voz-práxis literária em particular, um profundo papel epistemológico-político, que de modo correlato permite a autoafirmação e a autoexpressão dos indígenas por si mesmos e, depois, em consequência, sua práxis de crítica, resistência e luta social, cultural e política. No mesmo sentido, o xamã indígena pode, apelando para essa condição originária e fundante do horizonte antropológico-ontológico indígena, rememorando essa ancestralidade, essa criação e essa destinação originais dos povos indígenas (e, no caso, do povo yanomami em particular), assumir esse papel epistemológico-político e essa avaliação e esse enquadramento normativos acerca tanto da condição indígena quanto do próprio processo de modernização em seu sentido unidimensional e totalizante. Por outras palavras, é por meio do xamanismo e da condição-papel de xamã que se pode falar sobre normatividade e, com isso, que se tem condições de performatizar uma práxis crítico-emancipatória acerca da modernidademodernização. Note-se, com isso, que os xamãs não apenas possuem uma função religiosa, cívica e terapêutica frente à comunidade de que fazem parte, na medida em que, aqui, eles realizam a rememoração e a atualização permanentes de suas bases, de seus vínculos e de sua história ancestral, inclusive assumindo funções próprias a curandeiros; eles também e fundamentalmente, como no caso do xamã Davi Kopenawa, explicitam a organização antropológico-ontológica que subjaz, que perpassa, que está intrínseca à própria constituição mágico-animista da floresta viva, da qual fazemos parte diretamente, o que significa que eles explicitam, desvelam e apresentam a nossa - à humanidade em geral - condição antropológica, ontológica, religiosa e natural-material fundante. É nesse sentido, por conseguinte, que o xamã é um interlocutor tanto de seu povo e para seu povo quanto, no nosso caso aqui, da própria modernização, junto aos brancos. Sobre isso, vejamos a passagem que segue, d'A Queda do Céu:

Omama era o único a conhecer os xapiri e os deu ao seu filho, porque, se morresse sem ter ensinado suas palavras, jamais teria havido xamãs na floresta. Não queria 
que os humanos ficassem sem nada e causassem dó. Por isso, fez de seu filho o primeiro xamã. Deixou-lhe o caminho dos xapiri antes de desaparecer. Foi o que ele quis.

Disse a ele estas palavras: "Com estes espíritos, você protegerá os humanos e seus filhos, por mais numerosos que sejam. Não deixe que os seres maléficos e as onças venham devorá-los. Impeça as cobras e os escorpiões de picá-los. Afaste deles as fumaças de epidemia xawara. Proteja também a floresta. Não deixe que se transforme em caos. Impeça as águas dos rios de afundá-la e a chuva de inundá-la sem trégua. Afaste o tempo encoberto e a escuridão. Segure o céu, para que não desabe. Não deixe os raios caírem na terra e acalme a gritaria dos trovões! Impeça o ser tatu-canastra Wakari de cortar as raízes das árvores e o ser do vendaval Yariporari de vir flechá-las e derrubá-las". Essas foram as palavras que Omama deu ao filho. Por isso, até hoje os xamãs continuam defendendo os seus e a floresta. Mas também protegem os brancos, apesar de serem outra gente, e todas as terras, até as mais imensas e distantes.

[...] o filho de Omama foi o primeiro a virar espírito, antes de qualquer outro. Foi o primeiro a estudar e a ver as coisas com a yãkoana. Depois dele, muitos de nossos ancestrais se tornaram xamãs. Ele lhes mostrou como fazer dançar os espíritos. Disse a eles, como Omama lhe havia ensinado: "Quando os seres maléficos da floresta capturarem a imagem de seus filhos para devorá-la, os xapiri irão recuperála e vingá-los!". Foi seguindo estas palavras que os nossos maiores se puseram a beber o pó de yãkoana e admirar o esplendor dos espíritos. É isso que fazemos até hoje. Por isso, é tão comum ver os xamãs trabalhando em nossas casas. Sem eles, seriam vazias e silenciosas. Assim é. Essas palavras são antigas, mas nunca vão desaparecer, porque são muito bonitas e o valor delas é muito alto (KOPENAWA e ALBERT, 2015, p. 85-86).

Note-se, nesta passagem, que o xamã faz a ponte entre a criação original e o sobrenatural com a vida cotidiana da comunidade indígena e mais além. Por meio da yãkoana, ele consegue tornar-se espírito e acessar o mundo espiritual, seja no sentido de ouvir a voz dos espíritos e de perceber essa estrutura ontológica própria à vida fática, seja no sentido de clamar pela ajuda daqueles para enfrentar os problemas cotidianos de nós humanos, demasiado humanos. O xamanismo, com isso, dá condições para que o xamã veja a normatividade do mundo, sua conexão, sua correlação com a própria espiritualidade, por assim dizer, e o caráter inextricável e inultrapassável dessa constituição fundamentalmente normativa, dessa conexão entre todas as formas de vida e comunidades humanas, incluindose, aqui, o âmbito natural, bem como dessa correlação de espiritualidade e facticidade. Por isso, mais uma vez, o xamanismo torna-se também o lugar e o modo da reelaboração epistemológico-política dos indígenas por si mesmos e a base a partir do qual enquadram e analisam a modernização, o que também significa que é ele quem estabelece a ponte entre essa mesma comunidade indígena e os brancos, em uma tentativa de mediação. Aliás, nesse aspecto, salientamos passagem de Davi Kopenawa, explicitada na citação acima, em que os xamãs garantem tanto a interpretação da normatividade do mundo quanto a proteção de suas comunidades e também dos próprios brancos, tanto de sua floresta e de sua terra quanto 
também das florestas e das terras mais além. Ou seja, o xamanismo possui uma vocação universal, a proteção de todas as diferenças, algo que é comparável, teoricamente, a um pressuposto-chave do paradigma normativo da modernidade, a saber, de que a racionalização cultural-comunicativa gerada, desenvolvida e representada pela Europa moderna teria um alcance universal, enquanto paradigma epistemológico-político universalista, como guardachuva normativo das diferenças, por elas e para elas - e exatamente a partir da deslegitimação do tradicionalismo em geral, segundo palavras das próprias teorias da modernidade canônicas, enquanto gerador, sustentador e viabilizador desse mesmo universalismo (WEBER, 1984, p. 11-24; HABERMAS, 2012, p. 90-141).

Nesse sentido, Davi Kopenawa está utilizando o xamanismo enquanto base paradigmática e núcleo normativo tanto para sua apresentação e reconstrução da cultura yanomami, de sua visão antropológico-ontológica, a ser explicada aos brancos (já que os indígenas não precisam destas palavras escritas em peles de papel para entender, viver e valorizar sua cultura, sua forma de vida), quanto, de um modo mais geral, para a interpretação do próprio processo de modernização e, com isso, de seu diálogo-práxis com os brancos, arautos e portadores desse mesmo processo de modernização. O xamanismo lhe serve como chave-de-leitura analítica e como aguilhão político-normativo da crítica e do enquadramento do processo de modernização, tanto quanto lhe serve como fundamento simbólico-ontológico para a constituição e para a dinamização da própria autoafirmação, autoexpressão e autoconstituição. De todo modo, e isso é o mais importante no fato do xamanismo na e como literatura indígena, é exatamente por meio dele e, assim, a partir da voz-práxis xamânica que a crítica social, a resistência-luta política e a fundamentação da normatividade têm lugar, são legitimadas e realizadas. Prescinde-se, aqui, do paradigma normativo da modernidade e de seu cientificismo (em termos de racionalização analítica e de procedimentalismo imparcial, neutro, formal e impessoal em termos metodológico-programáticos) enquanto a condição viabilizadora da crítica, da luta e da justificação normativa.

Ora, como dissemos, o xamanismo é condição suficiente e inultrapassável tanto para a autoafirmação e a autoexpressão do indígena por si mesmo, de suas bases antropológicoontológicas, socioculturais e epistemológico-políticas, quanto para sua práxis de crítica, de enquadramento e de luta em relação à modernização. No exemplo de Davi Kopenawa, o que podemos perceber é exatamente a correlação de uma vocação universal do xamanismo, isto é, de fazer sempre e sempre a intermediação dessa ligação inextricável e umbilical entre o âmbito espiritual e a vida fática, em verdade desvelando e não nos deixando esquecer de que 
esses dois âmbitos convivem juntos, misturados (e não lado a lado) o tempo todo e permanentemente, bem como de possibilitar a proteção de todos os seres humanos, o que também significa que, exatamente por servir como guarda-chuva normativo para todos e por todos, para todas as diferenças e por todas elas, o xamanismo pode embasar, dinamizar e intermediar o diálogo-práxis intercultural, principalmente quando o problema mais central é a própria modernização totalizante e unidimensional. Nesse quesito, por conseguinte, se por um lado o xamanismo põe em xeque a viabilidade do modelo de modernização ocidental imoderado e unidimensional, que ele associa à mercantilização pura e simples (ou, pelo menos, concebendo a mercantilização e a coisificação como a tendência e o movimento mais basilares da modernização, principalmente quando ela atinge os povos indígenas em particular e a natureza de um modo mais geral), por outro ele pode assumir-se como base paradigmática da crítica, da transformação e da fundação da normatividade intersubjetivamente vinculante, colocando-se, assim, em pé de igualdade ao próprio paradigma normativo da modernidade. É por isso que o xamanismo, nessa sua vocação universal, o xamanismo como condição universal da vida, da efetividade e da estabilidade do mundo (incluindo-se, aqui, a própria sociedade humana), torna-se interlocutor privilegiado e fundamental da própria modernização.

\section{Literatura, xamanismo e a voz-práxis indígena: perspectivas epistemológico-políticas do xamanismo como voz-práxis literária}

A Queda do Céu, por conseguinte, estabelece o xamanismo como lugar e modo da crítica, colocando-o em pé de igualdade ao próprio paradigma normativo da modernidade, de cunho cientificista. Como fizemos ver na primeira parte, Davi Kopenawa percebe e afirma esse mesmo xamanismo como o ponto de encontro e de elaboração seja da posição antropológico-ontológica indígena, uma vez que ele permite rememorar sempre e permanentemente sua base e sua destinação ancestrais, seja do diálogo-práxis intercultural, na medida em que, aqui, o xamanismo é visto como base normativa universal e como instrumento analítico capaz de explicitar a conexão e a profunda dependência entre seres humanos e natureza, para não se falar em sua essencial constituição ontológica, religiosa, por assim dizer. É nesse sentido que o xamanismo, na e como literatura indígena, assume não apenas a tarefa de expressar e afirmar a cultura indígena por si mesma e para si mesma, enquanto autoexpressão, autoafirmação e auto-reconstrução simbólico-normativa dos povos indígenas sobre si mesmos, mas também e até fundamentalmente, no caso dessa produção 
indígena, a realização da crítica social e da luta política frente à modernização, bem como a própria mediação do diálogo-práxis intercultural em que essa mesma modernidademodernização é colocada em suspeição no que tange tanto à sua vocação universalista (como paradigma normativo da modernidade) quanto ao ideal de progresso sociocultural e de desenvolvimento político-econômico que ela representa e realiza dentro de si mesma e fora de si mesma (ALBERT, 1995). Incrivelmente, portanto, o xamanismo reestilizado é assumido e colocado diretamente como crítica à modernidade-modernização a partir do outro da modernidade, nesse caso o indígena, tornando-se aguilhão crítico e base político-normativa para o enquadramento da modernização, para sua problematização e transformação.

Não é acaso, nesse sentido, que Davi Kopenawa fale, como pudemos perceber em passagem de sua obra citada na primeira parte desse texto, que ele quer dar a conhecer aos brancos, via xamanismo, que a floresta é viva, e não morta; de que ela é completamente perpassada por normatividade e espiritualidade, não sendo, portanto, apenas uma estrutura mecânica determinada pela causalidade cega. Enfim, no caso de nosso xamã yanomami, a natureza é o próprio horizonte antropológico-ontológico a partir do qual o ser humano possui sentido e destino, de modo que, nela, será definida a própria condição presente e evidentemente o futuro desse mesmo homem, de todos os homens. A floresta, aliás, não apenas é perpassada por vida, senão que todo o desenrolar da existência, nessa trama marcada pela correlação de espiritualidade e materialidade, se dá dentro dela, a partir dela, ou seja, a floresta contém toda a vida e toda a dinâmica da vida e, com isso, nada há fora dela, tudo está dentro dela. Ora, como dizíamos, não é mero acaso que Davi Kopenawa confronte a modernidade-modernização a partir da afirmação de que a floresta é viva, e não morta, uma estrutura normativa, e não uma mera coisa, um puro e simples objeto. É que o paradigma normativo da modernidade coloca a sociedade moderna como o ápice do desenvolvimento humano e autêntico universalismo exatamente porque ela, marcada e dinamizada pela racionalização cultural-comunicativa, separa natureza ou mundo objetivo (objeto da técnica), sociedade ou cultura (objeto da política) e subjetividade ou individualidade (objeto da ética, como autoconsciência), ao passo que, em contrapartida, concebe as sociedades tradicionais, de base mágico-animista, como pré-modernas, no sentido de não serem racionais e universalistas, exatamente pela correlação e imbricação profundas entre natureza, sociedade ou cultura e individualidade em que o xamanismo, e não a ciência e nem a política, define o sentido das coisas, sua justificação à comunidade ao longo do tempo (WEBER, 1984; HABERMAS, 2012, GIDDENS, 1996). 
No caso das teorias da modernidade - citamos aqui, en passant, Max Weber, Jürgen Habermas e Anthony Giddens -, a contraposição entre modernidade e tradicionalismo e o correlato entendimento, por parte da modernidade, do outro da modernidade como nãoracional e não-universal apontam para o fato de que, se quisermos buscar justificação racional e alcançar o universalismo epistemológico-moral como condições normativas fundamentais para a realização da crítica social, da emancipação política e do diálogo-práxis intercultural, temos de fazer isso não nas sociedades-culturas pré-modernas ou tradicionais e a partir delas, mas sim exatamente na modernidade-modernização - e, aqui, na sociedade europeia moderna, que representa e é esse conceito de modernidade-modernização utilizado nas ciências sociais e na filosofia euronorcêntricas. Pois bem, nesse caso, as sociedades-culturas pré-modernas não permitem a construção de um paradigma normativo garantidor da crítica social, da emancipação política e do diálogo-práxis intercultural exatamente pelo fato de que, ao não separarem natureza ou mundo objetivo, sociedade ou cultura e individualidade, impedem a racionalização cultural-comunicativa, de modo que a constituição e a evolução da sociedade saem da mão dos indivíduos e dos grupos sociais e ficam situadas em deidades e poderes completamente alheios, extemporâneos e sobrepostos aos indivíduos e grupos sociais. Daí a afirmação fundamental, nas teorias da modernidade, de que não existe criticismo e mobilidade sociais nas culturas pré-modernas, posto elas não serem marcadas pela secularização culturalinstitucional e pela existência de uma noção forte de individualidade. Nessas culturas prémodernas, portanto, a natureza aparece antropomorficizada; a sociedade, em suas estruturas, relações e autoridades, aparece como naturalizada; e o indivíduo acaba sendo subsumido por essa constituição natural-societal-cultural totalizante e mágica (HABERMAS, 2012, p. 94).

Nesse contexto, e como antípoda das sociedades-culturas pré-modernas, a sociedadecultura moderna é racional e gera racionalização social, uma vez que, pela separação entre natureza, cultura-sociedade e individualidade via racionalização cultural-comunicativa, ela é caracterizada e dinamizada pela secularização institucional-cultural e pela consolidação de uma noção forte e fundante de subjetividade reflexiva. Portanto, aqui, a sociedade-cultura moderna, suas estruturas, suas relações e seus poderes vinculantes tornam-se desnaturalizados e politizados, ao mesmo tempo em que a natureza torna-se uma coisa, um objeto (a res extensa cartesiana). Isso leva a dois processos fundamentais que definem o caráter especial e singular da modernidade europeia quando comparada às sociedades-culturas pré-modernas, a saber: isso que Weber e Habermas chamam de diferenciação das esferas de valor próprias à sociedade-cultura moderna, de modo que, na modernidade, cada área da reprodução 
sociocultural possui dinâmicas, princípios, práticas, valores e autoridades muito próprios, que possuem, por conseguinte, formas específicas de fundamentação e de constituição - a sociedade-cultura moderna não é mais totalizante e unidimensional, constituída e dinamizada por um único princípio de legitimação e de integração, senão que possui vários e até concorrentes princípios de integração e de legitimação relativos a cada esfera da vida sociocultural (a economia é uma coisa, a política outra etc.); e à consolidação de uma cultura e de uma consciência cognitivo-moral descentradas, pós-tradicionais e, como consequência, universalistas, marcadas por uma postura não-egocêntrica e não-etnocêntrica no que tange à fundamentação dos valores e dinamizada por um procedimentalismo que é imparcial, neutro, formal e impessoal em termos metodológico-axiológicos (HABERMAS, 2012, p. 140-148).

Por isso a afirmação, por parte de Habermas, de que a sociedade-cultura moderna gera e solidifica uma consciência cognitivo-moral racionalizada, pós-convencional e pós-tradicional, altamente formalista e individualista, em que os indivíduos e os grupos sociais são educados a pensar, agir e fundamentar não mais a partir da referência a uma base metafísico-religiosa concretista (como é o caso das sociedades-culturas pré-modernas e em termos de xamanismo), mas apenas a partir de princípios genéricos e desde um sentido imparcial, impessoal e neutro. Os indivíduos e grupos modernos pensam, agem e fundamentam a partir da formalização dos valores e dos sujeitos, contrariamente aos indivíduos e grupos das sociedades pré-modernas que, sendo destituídas de racionalização cultural-comunicativa em sentido forte, fazem com que aqueles pensem, ajam e fundamentem a partir da referência e da dependência intrínsecas e diretas ao próprio contexto de emergência. Por isso, as sociedades modernas são, a partir da correlação e do mútuo suporte de racionalização cultural-comunicativa e de procedimentalismo imparcial, neutro, formal e impessoal, universalistas, capazes de falar, agir e fundamentar em nome da humanidade como um todo, sem ficarem restritas ao próprio horizonte sociocultural e antropológico-ontológico que lhes funda. É nesse sentido que o paradigma normativo da modernidade, constituído como procedimentalismo imparcial, neutro, formal e impessoal, e dinamizado em termos de racionalidade cultural-comunicativa, é alçado a modelo normativo fundamental da justificação intersubjetiva, da crítica social e da emancipação política, dentro da modernidade e fora dela. E, com isso, a modernidademodernização é correlacionada (a) com racionalização, crítica, reflexividade, emancipação e universalismo, bem como (b) com racionalização, universalismo e gênero humano, representando-o e podendo falar em nome dele, oferecendo a base paradigmática e os instrumentos analíticos para seu enquadramento e orientação (mesmo consciente do perigo do 
etnocentrismo de que essa posição parte e o qual ela pode acarretar) (WEBER, 1984, p. 11-24; HABERMAS, 2012, p. 90-148; GIDDENS, p. 95-175).

Nesse caso, para o paradigma normativo da modernidade, de antemão as epistemologias pré-modernas (não marcadas pela correlação de racionalização cultural-comunicativa e de procedimentalismo imparcial, neutro, formal e impessoal) não alcançam o nível de justificação pós-convencional ou universalista e, com isso, não apenas não conseguem estar em igualdade de condições relativamente ao paradigma normativo da modernidade, senão que, se quiserem alcançar um tal nível epistemológico-normativo, devem assumir o próprio procedimentalismo como condição da expressão e da legitimação intersubjetivas da vozpráxis própria, racionalizando suas práticas, valores e sujeitos - os sujeitos epistemológicopolíticos tradicionais devem ou tornar-se modernos, ou assumir alguns de seus pressupostos teórico-políticos fundamentais. Pois bem, como dizíamos acima, nós consideramos extremamente inteligente e central o argumento de Davi Kopenawa de que ele quer, por meio d'A Queda do Céu, em explicitando sua base antropológico-ontológica via voz-práxis xamânica, mostrar e alertar aos brancos de que a floresta é viva, e não morta, de que ela possui normatividade, não podendo ser coisificada e instrumentalizada. Ora, essa posição não apenas ataca de modo direto a separação entre natureza ou mundo objetivo, sociedade ou cultura e individualidade feita pelas teorias da modernidade euronorcêntricas, inclusive negando essa ideia de que a natureza seja uma mera estrutura instrumental, senão que, em religando essas três esferas separadas pela modernidade, devolve aos povos indígenas o direito de assumirem sua base antropológico-ontológica como geradora de compreensão, justificação e normatividade, a partir da qual eles fundamental, dinamizam e orientam sua própria voz-práxis em termos público-políticos.

Com efeito, o argumento central de Davi Kopenawa está em que o xamanismo permite desvelar seja essa base antropológico-ontológica que subjaz à vida humana de um modo geral (e não apenas às sociedades-culturas indígenas em particular), seja a normatividade inerente à vida em sua correlação de espiritualidade, natureza e materialidade. Por isso mesmo, não é preciso e nem necessário, para ele, assumir o paradigma normativo da modernidade como condição da crítica, da emancipação e do diálogo-práxis intercultural. O xamanismo é completamente capaz de falar normativa e politicamente, porque desvela a ligação ontológica fundamental entre as três esferas separadas pela modernidade, reinserindo a sociedade-cultura e a individualidade dentro do horizonte mais amplo representado pela natureza enquanto intersecção de espiritualidade, materialidade e cultura. No mesmo sentido, a crítica à 
modernidade, nesse sentido de coisificar e instrumentalizar a natureza, aponta para um fato óbvio a essa mesma modernidade, a saber, a crise ecológica como um de seus mais graves problemas e um de seus mais pungentes desafios de nossa época e dos tempos vindouros. Note-se que, devido à separação entre natureza ou mundo objetivo, sociedade ou cultura e individualidade, a crise ecológica parece ser uma questão extemporânea à vida cotidiana do homem ocidental e um problema técnico que será resolvido com mais ciência instrumental. De todos os modos, ela pouco nos concerne e não nos preocupa em absoluto, sequer aparecendo na esfera público-política de modo sério. Ora, nesse quesito, Davi Kopenawa nos chama a atenção para o fato de que, ao separarmos e tornarmos independentes natureza, sociedade ou cultura e individualidade, mundo físico-biológico e vida humana, acabamos deixando a questão ecológica em segundo plano, periferizada frente a questões existenciais ou políticas mais específicas. Entretanto, se levássemos a sério a questão ecológica, acabaríamos diretamente abordando essas mesmas questões sociais, políticas, culturais e epistemológicas que vêm diretamente no bojo da compreensão que temos acerca da natureza. Em particular, como Davi Kopenawa insiste ao longo do texto, se a natureza for destruída, os povos indígenas e também os brancos serão severamente impactados, talvez destruídos juntamente, e por causa da destruição daquela. Por outras palavras, em Davi Kopenawa, há uma conexão ao mesmo tempo material e normativa entre a natureza e os seres humanos, e dos seres humanos entre si, representada pela existência, pela estabilidade e pela permanência da floresta, e aqui estaria o ponto comum, fundante e dinamizador do diálogo-práxis intercultural e, em consequência, da crítica à modernidade-modernização. Não por acaso, se as teorias da modernidade estabelecem a racionalização como o ponto fundante da normatividade, Davi Kopenawa, ao enfatizar a questão ecológica, desloca esse eixo de interpretação, atribuindo à natureza - na correlação de espiritualidade, materialidade e cultura - uma constituição fundamentalmente normativa que necessita ser explicitada e desvelada para que não continuemos a instrumentalizá-la e coisificá-la em termos mercantis (VIVEIROS DE CASTRO, 2002; MIGNOLO, 2007; CLIFFORD, 2008; FERNANDEZ, 2013).

Outro ponto importante e correlato a este consiste na própria expressão literária da vozpráxis xamânica indígena. Na nossa percepção, A Queda do Céu: Palavras de Um Xamã Yanomami não poderia ser constituída e dinamizada a não ser como voz-práxis literária. Ela não poderia ser uma obra filosófica aos moldes tradicionais que, por conseguinte, deveria abandonar o recurso epistemológico-político-normativo ao xamanismo e a explicitação dessa base antropológico-ontológica marcada pela criação ancestral e pela correlação de 
espiritualidade e materialidade e cultura. Ela também não necessitaria ser reconstruída por um antropólogo ou por um cientista social que traduziria ou explicitaria essa voz-práxis em nome do xamã. Se por um lado é verdade que Bruce Albert, co-autor da obra, adéqua o relato de Davi Kopenawa à escrita formal, por outro é exatamente o próprio xamã Davi Kopenawa que constrói sua narrativa-práxis desde sua perspectiva, assumindo a autoridade adveniente de sua condição xamânica que lhe permite acessar e reconstruir essa criação e essa destinação originárias, ancestrais, utilizando-a como aguilhão crítico-normativo em relação à modernização - nesse sentido, A Queda do Céu é, na medida em que se constitui como crítica da modernidade, uma obra fundamentalmente política, de uma minoria por si mesma e desde si mesma (MUNDURUKU, 2004; GRAÚNA, 2013; LIBRANDI-ROCHA, 2012; KLINGER, 2006). É nesse sentido que ela não pode ser enquadrada e nem desenvolvida com base em uma perspectiva cientificista. Os instrumentos e valores analíticos próprios ao paradigma normativo da modernidade em sua constituição cientificista, a saber, a imparcialidade, a neutralidade, a formalidade e a impessoalidade metodológico-axiológicas, todos eles dependentes de uma forte dose de racionalização científica, simplesmente deslegitimariam e ridicularizariam de antemão uma tal voz-práxis xamânica que afirma-se como tendo condições de reconstruir e de rememorar o processo original da criação do mundo e da própria constituição normativa desse mesmo mundo, podendo, em consequência, tanto enquadrar crítica e politicamente o processo de modernização ocidental quanto servir como base paradigmática universal de todos e para todos para a discussão dele e sobre ele.

Em contrapartida, como voz-práxis literária, a perspectiva xamânica de Davi Kopenawa pode expressar-se em sua singularidade e em sua espontaneidade, como ela é, como ela se autocompreende e desde as fontes e recursos que ela assume como sua base e sua especificidade. Com efeito, a literatura é um campo anti-paradigmático e anti-cientificista por excelência, que destoa de modo direto do modelo cientificista e formalista das ciências humanas e sociais, recusando qualquer sentido técnico tanto ao método quanto à construção e à expressão do saber expresso pelo sujeito que explicita e dinamiza sua voz-práxis. Dito de outro modo, na literatura são exatamente a carnalidade, a politicidade e a vinculação dos sujeitos do discurso-práxis que realmente importam e que realmente definem o sentido e a pungência do texto-práxis. Aqui, a racionalização analítica e o procedimentalismo imparcial, neutro, formal e impessoal em termos metodológico-axiológicos, enquanto definidores da justificação, do sentido e da validade intersubjetivos dos conteúdos, das práticas e da atuação dos sujeitos, simplesmente não contam. Nesse sentido, a voz-práxis literária é sempre 
fundada, constituída e dinamizada na primeira pessoa do singular e na terceira pessoa do singular, principalmente quando falamos em literatura indígena, em que há uma indissociabilidade, mútua projeção e suporte recíproco entre o eu-nós lírico (ALMEIDA, 2005; ALMEIDA, 2009; FINNEGAN, 2006; RISÉRIO, 1993; FEIL, 2011). Por isso mesmo, na vozpráxis literária, constituída sempre em termos desse eu-nós lírico e sendo marcada por uma carnalidade, uma politicidade e uma vinculação estritas, se explicita e se desvela o profundo sentido da alteridade, o que torna, como vimos dizendo, a voz-práxis literária como espaço e modo das diferenças por si mesmas, para si mesmas e desde si mesmas.

Desse modo, somos levados a perceber e a aprender que a condição da crítica, da emancipação, da reflexividade e mesmo do diálogo intercultural é exatamente a posição epistemológico-política e a voz-práxis das minorias por elas mesmas e desde si mesmas. Esta é uma posição e uma condição que não pode ser racionalizada e nem formalizada, que não pode ser percebida e dinamizada desde uma perspectiva neutra, imparcial e impessoal. A vozpráxis da crítica e da emancipação, que é por excelência plural como o são os sujeitos e as posições epistemológico-políticas, uma vez sendo assumida, dinamizada e definida como vozpráxis das diferenças, das minorias e das vítimas por si mesmas, assume um sentido direta e pungentemente carnal, político e politizante, vinculado, e somente assim pode ser compreendida, explicitada e definida - inclusive, somente a partir dessa perspectiva ela pode ser enquadrada e avaliada. A condição e o modo das minorias, das vítimas e das diferenças em geral, sua voz-práxis totalmente singularizada porque carnal, política e vinculada, não pode ser tornada científica e racionalizada por um paradigma extemporâneo a ela sob pena de pagar-se o intolerável preço de sua negação qua diferença, qua minoria, qua vítima, e mesmo sob pena de uma descaracterização que é conseqüência muito freqüente e própria do cientificismo assumido e dinamizado pelo paradigma normativo da modernidade. É aqui que Davi Kopenawa, n’A Queda do Céu, estabelece sua voz-práxis desde seu próprio lugar e a partir de sua condição, com base em seu horizonte antropológico-ontológico. Nele, o xamanismo enquanto voz-práxis que desvela a origem do mundo e sua constituição profundamente normativa não apenas assume lugar central como práxis constitutiva e fundamentadora, mas também, conforme estamos enfatizando, como aguilhão crítico, político e normativo em relação à modernidade, o que nos permite defini-lo diretamente como crítica à modernidade. Aqui, também o caminho da voz-práxis indígena por meio do xamanismo e de sua expressão literária acaba sendo explicitado, dinamizado e definido: da autoafirmação e da 
autoexpressão identitárias à crítica em relação à modernização, frente à violência e à negação sofridas.

\begin{abstract}
Apesar de tudo isso, os brancos já nos ameaçaram muitas vezes para nos obrigar a abandonar os xapiri. Nessas ocasiões, só sabiam dizer: "Seus espíritos estão mentindo! São fracos e estão enganando vocês! São de Satanás!”. No começo, quando eu ainda era muito jovem, tinha medo da fala desses forasteiros e, por causa delas, cheguei a duvidar dos xapiri. Por algum tempo, me deixei enganar por essas más palavras e até tentei, com muito esforço, responder às palavras de Teosi. Mas isso acabou mesmo! Faz muito tempo que eu não deixo mais as mentiras dos brancos me confundirem e que não me pergunto mais: "Por que eu não tento virar um deles?". Tornei-me homem, meus filhos cresceram e tiveram seus próprios filhos. Agora, nunca mais quero ouvir más palavras sobre os xapiri! Omama os criou depois de ter desenhado nossa floresta e, desde então, eles continuaram cuidando de nós. Eles são muito valentes e muito bonitos. Seus cantos fazem nosso pensamento aumentar em todas as direções e ficar firmes. E por isso vamos continuar fazendo dançar suas imagens e defendendo suas casas, enquanto estivermos vivos. Somos habitantes da floresta. É o nosso modo de ser e são estas palavras que quero fazer os brancos entenderem (KOPENAWA e ALBERT, 2015, p. 511).
\end{abstract}

\title{
Referências
}

ALBERT, Bruce. "O ouro canibal e a queda do céu: uma crítica xamânica da economia política da natureza”. In: Série Antropologia, n. 174, 1995.

ALBERT, Bruce. "Postscriptum: quando eu é um outro (e vice-versa)", p. 512-549. In:

KOPENAWA, Davi; ALBERT, Bruce. A queda do céu: palavras de um xamã yanomami. São Paulo: Companhia das Letras, 2015.

ALMEIDA, Maria Inês de. "A escrita da comunidade ou um estilo indígena na literatura do Brasil". In: PERES, Ana Maria Clark (org.). O estilo na contemporaneidade. Belo Horizonte: Faculdade de Letras da UFMG, 2005, v.1, p. 97-106. Disponível em: <http://www.letras.ufmg.br/poslit>.

ALMEIDA, Maria Inês de. Desocidentada: experiência literária em terra indígena. -Belo Horizonte: Editora UFMG, 2009.

ALMEIDA, Maria Inês de; QUEIROZ, Sônia. (org.). Na captura da voz - as edições da narrativa oral no Brasil. Belo Horizonte: Autêntica; FALE/UFMG, 2004.

BONVINI, Emilio. "Textos orais e texturas orais”. In: Queiroz, S. A tradição oral. FALE/UFMG, 2006. p. 5-24.

CLIFFORD, James. A experiência etnográfica: antropologia e literatura no século XX. Rio de Janeiro: Editora UFRJ, 2008.

COSTA, Suzane Lima. "Povos indígenas e suas narrativas autobiográficas". In: Estudos Linguísticos e Literários, n. 50, p. 65-82, jul-dez, Salvador, 2014. 
COSTA, Suzane Lima; XUCURU-KARIRI, Rafael. "Conversações sobre povos indígenas em práxis autobiográficas”. In: Pontos de Interrogação, v.4, n.2, jul./dez, p. 85-98, Bahia, 2014.

D'ANGELIS, Wilmar da Rocha. Como nasce e por onde se desenvolve uma tradição escrita em sociedades de tradição oral? Campinas: Curt Nimuendajú, 2007.

DORRICO, Julie. "A mídia e a literatura como ferramenta de autoafirmação e re-existência dos povos indígenas na contemporaneidade". In: CEI, Vitor et al. O que resta das jornadas de junho. Porto Alegre: Editora Fi, 2017.

FEIL, Roselene Berbigeier. "O (não) lugar do indígena na "literatura brasileira”: por onde começar a inclusão?” In: Boitatá (Londrina), p. 122-137, 2011.

FERNANDES, Estevão Rafael. "Ensino de filosofia e cultura amazônica: Uma apologia aos saberes periféricos". In: DANNER, L. F. (Org.). Ensino de Filosofia e Interdisciplinaridade. Porto Alegre: Editora Fi, 2013, p. 124-148.

FINNEGAN, Ruth. "O significado da literatura em culturas orais”. In: QUEIROZ, S. (Org.) A tradição oral. FALE/UFMG, 2006. p. 64-102.

GRAÚNA, Graça. Contrapontos da literatura indígena contemporânea no Brasil. Belo Horizonte: Mazza Edições, 2013.

GIDDENS, Anthony. Para além da direita e da esquerda: o futuro da política radical. São Paulo: Editora da UNESP, 1996.

HABERMAS, Jürgen. Teoria do agir comunicativo (Vol. I): racionalidade da ação e racionalização social. São Paulo: Martins Fontes, 2012.

KLINGER, D. I. Escritas de si, escritas do outro: autoficção e etnografia na narrativa latino-americana contemporânea. Tese de doutorado, Programa de Pós-Graduação de Letras da UERJ, Rio de Janeiro, 2006.

KOPENAWA, Davi; ALBERT, Bruce. A queda do céu: palavras de um xamã yanomami. $1^{a}$ edição, São Paulo: Companhia das Letras, 2015.

LIBRANDI-ROCHA, Marília. "Escutar a escrita: por uma teoria literária ameríndia". In: O eixo e a roda, ISSN 0102-4809, v. 21, n. 2, 2012.

MIGNOLO, Walter. La idea de América Latina: la herida colonial y la opción decolonial. Barcelona: Editorial Gedisa, 2007.

MUNDURUKU, Daniel. "Visões de ontem, hoje e amanhã: é hora de ler as palavras", p. 1516. In: POTIGUARA, Eliane. Metade cara, metade máscara. São Paulo: Global, 2004.

RISÉRIO, Antônio. Textos e tribos - Poéticas extraocidentais nos trópicos brasileiros. Rio de Janeiro: Imago Ed., 1993.

SÁEZ, Oscar Calavia. “Autobiografia e sujeito histórico indígena”. In: Novos Estudos (CEBRAP), n. 76, p. 179-195, São Paulo, 2006. 
VIVEIROS DE CASTRO, Eduardo. A inconstância da alma selvagem e outros ensaios de antropologia. São Paulo: Cosac Naify, 2002.

VIVEIROS DE CASTRO, Eduardo. "Prefácio: o recado das matas", p. 11-41. In:

KOPENAWA, Davi; ALBERT, Bruce. A queda do céu: palavras de um xamã yanomami. São Paulo: Companhia das Letras, 2015.

WEBER, Max. Ensayos sobre sociología de la religión (T. I). Madrid: Taurus, 1984.

Recebido em 20/03/2018 Aceito para publicação em 11/06/2018 